\title{
Sosyal Dezavantajlı Bölgedeki Ortaokul Öğrencilerinin Anneye Bağlanma ve Sosyal Destek Alg1si*
}

\author{
Hatice BEKİR ${ }^{1}$, Güldeniz ARBAŞ², Remzi AYDIN³ \\ ${ }_{1}^{1}$ Dos..Dr.,Gazi Üniversitesi, bsimsek.bekin@gmail.com, shatice@gazi.edu.tr \\ ²Örretmen, Milli Ë̆̈itim Bakanliğ, guldenizarbas@gmail.com \\ ${ }^{3}$ Y.L. Ögrrencisi,Gaæi Üniversitesi, remziaydin@msn.com
}

Bu Araştırma, sosyal dezavantajlı bölgede yaşayan ortaokul öğrencilerinin anneye bağlanma ve sosyal destek algilarını belirlemek amacı ile planlanmışıtır ve yürütülmüştür. Nicel araştırma desenlerinden betimsel ilişskisel tarama modelinde olan bu çalıșmanın çalıșma grubunu 2014-2015 eğitim ve öğretim yılında Diyarbakır İli Silvan İlçesine bağı bir köyde bulunan bir ortaokul'un 5.6.7.ve 8.sınıflarına devam eden 211 öğrenci oluşturmaktadır. Araştırmaya katılımda gönüllülük esas alınmıştır. Veriler, araştırmacılar tarafından toplanmış ve verilerin toplanmasına geçmeden önce öğrencilere çalışsma ile ilgili bilgilendirme yapılmışır. Veri toplama aracı olarak araştırmacılar tarafindan hazırlanan genel bilgi formunun yanında "Yakın İlişkilerde Yaşantılar Envanteri II (YIYE-II) - Orta Çocukluk Ölçeği- Anne Formu" ile "Çok Boyutlu Algılanan Sosyal Destek Ölçeği’nin Gözden Geçirilmiş Formu (ÇBASDÖ)" kullanılmıştır. Çalışmada verilerin analizi SPSS 21.0 programı ile yapilmış ve analizlerde \% $\% 5$ güven ile çalışılmışıtır. Normallik testi sonucu ölçek puanlarının normal dağılıma uygun olmadığının belirlenmesi sebebi ile puanların kişisel değiş̧kenlere göre farklll1k gösterme durumunun analiz edilmesinde parametrik olmayan test tekniklerinden Mann-Whitney U ve Kruskal Wallis testleri, öğrencilerin çok boyutlu alg̣lanan sosyal destek ve alt boyutları ile bağlanma ve alt boyut düzeyleri arasındaki ilişkinin incelenmesi amacı ile Spearman Korelasyon testi kullanılmıştır. Araştırma sonucunda çok boyutlu algılanan sosyal desteğin aile boyutu, arkadaș boyutu ve çok boyutlu algılanan sosyal destek ölçeği ile bağlanmanın kaygı boyutu arasında negatif yönlü zayıf bir ilişki bulunmuştur. Buna rağmen çok boyutlu algılanan sosyal desteğin aile boyutu, arkadaş boyutu ve çok boyutlu algılanan sosyal destek ile bağlanmanın kaçınma boyutu ve bağlanma ölçeği arasında negatif yönlü orta kuvvetli bir ilişsi bulunmuştur. Çok boyutlu algilanan sosyal desteğin özel bir insan boyutu ile kaygılı ve kaçınan bağlanma boyutları ve bağlanma arasında bir ilişki bulunmamıştır.

Anahtar Kelimeler: Sosyal dezavantaj, ortaokul öğrencileri, anneye bağlanma, sosyal destek alg1sı

\section{Maternal attachment and Social Support Perception of Secondary School}

\section{Students in A Socially Disadvantaged Region}

\begin{abstract}
This study was designed and made to detect level of maternal attachment and social support perception of the secondary school students living in a socially disadvantaged region.Designed as a descriptive relational screening model, the study group consisted of 211 secondary school students to have attended at the $5^{\text {th }}, 6^{\text {th }}, 7^{\text {th }}$ and $8^{\text {th }}$ grades of a village affiliated to Silvan District of Diyarbakır Province. A general information form prepared by the researchers and "Experiences in Close Relations Inventory II- Middle Childhood Period-Mother Form" and revised form of "Multi-Dimensional Perceived Social Support Scale" were used as data collection tool in the scope of the study. Study data analyses were made using SPSS 21.0 package program. At the end of the study, anxiety dimension of attachment was found to have a low-level relationship with the family and peer dimensions of multi-dimensional perceived social support and Multi-Dimensional Perceived Social Support Scale. A mid-level negative relationship was also revealed between the family and peer dimensions of multi-dimensional perceived social support and multi-dimensional perceived social support, on one hand, and avoidance dimension of attachment and attachment scale, on the other hand. No relationship was detected between the specific person dimension of the multi-dimensional perceived social support, on one hand, and anxious and avoidance attachment dimensions and attachment.
\end{abstract}

Keywords: Social disadvantage, secondary school students, maternal attachment, social support perception

\footnotetext{
* Bu çalısma, 05-07 Kasım 2015 tarihleri arasında Girne’da düzenlenen “6. Uluslararası Eğitim Yönetimi Forumu”nda sunulan sözlü bildirinin genişletilmiş şeklidir.
} 


\section{GİRIŞ}

Bağlanma kuramı, John Bowlby ve Mary Ainsworth'un çalışmaları ve araştırmaları üzerine temellenir. Kuram, insanların kendileri için önemli olan başka kişilerle güçlü duygusal bağlar kurma eğiliminin nedenlerini açıklayan bir yaklaşımdır. Temel prensibi, erken dönemlerde anne veya bakım veren kişi ile kurulan ilişki sonrası yaşamdaki sosyal ilişkilerin tek tipidir. Bu anlamda insanların kendileri için önemli olan diğerleri ile duygusal bağ kurma eğiliminin nedenlerini açıklayan bir yaklaşımdır (Ünal, 2011).

Bowlby (1973; 1982), bebeklik döneminde temeli atılan duygu, düşünce ve davranış örüntülerinin "beşikten mezara" kadar sürdüğünü ve gelişim süreci içinde diğer yakıı ilişkilere de genellendiğini öne sürmüştür. Bağlanma kuramına göre güvenli bağlanma geliştiren çocuklar bağlanma figürlerini (genellikle ebeveynler) stres ve gerilim anlarında güvenli bir sığınak, oyun sırasında ya da stres hissetmedikleri durumlarda ise güvenli bir "keşif üssü” olarak başarıyla kullanabilirler. Güvenli bağlanmanın duyarlı, zamanında ihtiyaca cevap veren ve tutarlı ebeveyn davranışının bir sonucu olduğu çok sayıda araştırma tarafından desteklenmiştir (Main, Kaplan ve Cassidy 1985; Cassidy, 1999). Bireysel bağlanma farklılıklarını sistematik bir şekilde ölçmeyi amaçlayan Ainsworth, Blehar, Waters ve Wall (1978) yaptıkları gözlemler ve çalışmalar sonucunda anneyle çocuk arasındaki bağlanma modellerini güvenli, kaçınan ve kaygılı/kararsız bağlanma olarak üç kategoride sınıflamışlardır. Bu bağlamda geliştirdikleri "Yabancı Ortam” gözlem yöntemi ile bebeklerin annelerinden kısa süreli ayrı kalma durumlarında verdikleri tepkileri bağlanma kategorilerine göre değerlendirmişlerdir. Ayrılık sonrası annelerini sıcak karşılayan veya yakınlık gösterildiği takdirde kolayca sakinleşen bebekler güvenli bağlanan; rahatlamakta zorlanan ve kararsızlık yaşayan bebekler kayg1l/kararsız bağlanan; fiziksel ve psikolojik yakınlıktan kaçınan bebekler ise kaçınan bağlanan olarak tanımlanmıştır.

Birçok bilim adamı ve araştırmacılar tarafindan sosyal destek kavramı farklı değerlendirmelerle tanımlanmıştır. Bu araştırmacılardan biri olan Cobb (1976), sosyal destek için kişiyi sevildiğine, değer ve önem verildiğine ve iletişim ağının bir parçası olduğuna inandıran bir bilgi ifadesini kullanmıştır. Güncel bir tanımda ise sosyal destek, bir kişiye diğer kişilerce sağlanan maddi, duygusal veya bilişsel destek olarak tanımlanmıştır (Öztürk ve Şirin, 2000). Orta çocukluk ve ergenliğe geçişte çocuk ya da ergen yeni alanlarda kendi başına yaşantı denemelerine girmekle bazı yararlar elde edecek veya aksine, başardığı, korktuğu ya da kendini yetersiz hissettiği zamanlarda sosyal destek alacak birilerini bulması onu ferahlatacaktır (Yavuzer, 1986; Temel ve Aksoy, 2016). Bu dönemde, diğer bireylerle sağlanan etkileşim ve destek; sorunlara çözüm üretme, ileriye yönelik sağlıklı ilişkiler kurmada, uygun kararlar verebilmede ve umutlu bir bakış açısı kazanmada çok etkili olmaktadır (Yıldırım, 1998).

Çocuğun anneye bağlanma ve sosyal destek algıları çocuğun ileriki yaşamını etkileyecek önemli faktörler arasında yer almaktadır. Ancak sosyal açıdan dezavantajlı ailelerde eğitimsizlik, yoksulluk, aile içi uyumsuzluk vb. durumlardan dolayı güvenli bağlanma ve gerektiğinde sosyal desteğe açık olma durumu tam olarak yerine getirilememekte, çocuklar bu durumdan olumsuz etkilenmekte ve toplumun genelinde risklere açık olarak yaşamaktadır. Bu düşünceyi Bronfenbrenner’in ekolojik sistemler kuramının mikro sisteminde yer alan aile, okul ve çevreden kaynaklı risk faktörlerine karşı koruyucu faktörlerin alınması görüşü desteklemektedir. Koruyucu faktörlerin alınması içinde çocuğun anneye bağlanma ve sosyal destek algılarının belirlenmesi gereklidir. Literatürde ortaokul öğrencilerinin sosyal destek (Baltacı ve Karataş, 2015; Çakmak ve Şahin, 2017; Karadağ, 2007; Levitt, Guacci-Franco ve Levitt, 1994; Nowakowska, 2014; Şahan ve Duy, 2017) ve anneye bağlanma (Kırımer, Akça ve Sümer, 2014; Lieberman, Doyle ve Markiewicz, 1999; Sumbaş ve Sezer, 2017; Sümer ve Anafarta-Şendağ; 2009) ile ilgili çalışmalara rastlansa da yapılan çalışma sayısının az olması Diyarbakır İli Silvan İlçesinde yapılmış bir çalışmaya rastlanmaması ve mevcut araştırma bulgularına yenilerinin eklenmesi bakımından önemlidir.

\subsection{Araştırmanın Temel Amacı ve Alt Amaçları}

$\mathrm{Bu}$ araştırma, sosyal dezavantajlı bölgede yaşayan ortaokul öğrencilerinin anneye bağlanma ve sosyal destek algılarının belirlenmesi temel amacı ile planlanmış ve yürütülmüştür. Bu temel amaç doğrultusunda aşağıdaki sorulara cevap aranmıştır. 
- Sosyal dezavantajlı bölgede yaşayan ortaokul öğrencilerinin anneye bağlanma ve sosyal destek algiları ne düzeydedir?

- Sosyal dezavantajlı bölgede yaşayan ortaokul öğrencilerinin anneye bağlanma ve sosyal destek algıları arasında anlamlı bir ilişki var mıdır?

- Sosyal dezavantajlı bölgede yaşayan ortaokul öğrencilerinin cinsiyet, yaş, kardeş sayısı, anne-baba eğitim durumu, anne-baba çalışma durumu ve anne-baba tutumu değişkenlerine göre anneye bağlanma ve sosyal destek algıları anlamlı bir farkl11ı göstermekte midir?

\section{YÖNTEM}

\subsection{Araştırmanın Modeli}

Araştırma, genel tarama modellerinden ilişkisel tarama modelinde bir çalışmadır. İlişkileri ve bağlantıları inceleyen araştırmalar, ilişkisel (associational) araştırmalar olarak adlandırılır (Büyüköztürk, Kılıç-Çakmak, Akgün, Karadeniz ve Demirel, 2017).

\subsection{Araştırmanın Çalışma Grubu}

Çalışma grubunu 2014-2015 eğitim ve öğretim yllında Diyarbakır İli Silvan İlçesine bağlı bir köyde bulunan bir ortaokul'un 5.6.7.ve 8.sınıflarına devam eden 211 öğrenci oluşturmaktadır. Çalışmanın verilerinin toplandığı okulun belirlenmesinde sosyal dezavantajlı öğrenci profiline sahip olması ve araştırmacının okula kolay ulaşabilmesi göz önünde bulundurulmuştur. Çalışma grubunu oluşturan öğrencilere ve ebeveynlerine ilişkin bilgiler Tablo 1'de yer almaktadır.

Tablo 1. Öğrencilerin kişisel bilgilerine göre dağıllımı $(\mathrm{n}=211)$

\begin{tabular}{|c|c|c|c|}
\hline & & $\mathrm{n}$ & $\%$ \\
\hline \multirow{2}{*}{ Yaş } & $10-11$ & 43 & 20,4 \\
\hline & $12-13$ & 168 & 79,6 \\
\hline \multirow{2}{*}{ Cinsiyet } & $\mathrm{K}_{1 z}$ & 106 & 50,2 \\
\hline & Erkek & 105 & 49,8 \\
\hline \multirow{4}{*}{ Sinif } & 5.Sinif & 41 & 19,4 \\
\hline & 6.Sinif & 60 & 28,4 \\
\hline & 7.Sinif & 49 & 23,2 \\
\hline & 8.Sinif & 61 & 28,9 \\
\hline \multirow{5}{*}{ Kardeş Sayısı } & $1-2$ & 17 & 8,1 \\
\hline & $3-4$ & 41 & 19,4 \\
\hline & $5-6$ & 89 & 42,2 \\
\hline & $7-8$ & 43 & 20,4 \\
\hline & 9 ve üstü & 21 & 10,0 \\
\hline \multirow{3}{*}{ Annenin Eğitim Durumu } & Okur-yazar değil & 155 & 73,5 \\
\hline & Okur-yazar & 32 & 15,2 \\
\hline & İlkokul ya da ortaokul & 24 & 11,4 \\
\hline \multirow{5}{*}{ Babanın Eğitim Durumu } & Okur-yazar değil & 47 & 22,3 \\
\hline & Okur-yazar & 47 & 22,3 \\
\hline & İlkokul & 87 & 41,2 \\
\hline & Ortaokul & 22 & 10,4 \\
\hline & Lise & 8 & 3,8 \\
\hline \multirow{2}{*}{ Annenin Çalışma Durumu } & Çalışıyor & 16 & 7,6 \\
\hline & Çalışmiyor & 195 & 92,4 \\
\hline \multirow{3}{*}{ Babanın Çalışma Durumu } & Çalışıyor & 91 & 43,1 \\
\hline & Çalışmiyor & 113 & 53,6 \\
\hline & Emekli & 7 & 3,3 \\
\hline
\end{tabular}

Tablo 1 incelendiğinde katıllımcıların \%79,6’sının 12-13, \%20,4'nün ise 10-11 yaşında olduğu \%50,2'sinin kız, \%49,8'nin erkek olduğu görülmektedir. Katılımcılardan \%28,9’u 8.sınıfa, \%28,4’ü 6.sinıfa, \%23,2'si 7.sınıfa, \%19,4’ü 5.sınıfa devam etmektedir. Yüzde 42,2 ile kardeş sayıs1 5-6 olanlar ilk sırada yer almaktadır. Katılımcilar arasında annesi okur-yazar olmayanlar $(\% 73,5)$, babasi ilkokul mezunu olanlar (\%41,2), annesi çalışmayanlar $(\% 92,4)$ ve babası çalışmayanlar $(\% 53,6)$ en fazla orana sahiptir. 


\subsection{Veri Toplama Araçları}

Veri toplama aracı olarak araştırmacılar tarafindan hazırlanan genel bilgi formu'nun yanında "Yakın İlişkilerde Yaşantılar Envanteri II (YIYYE-II) - Orta Çocukluk Ölçeği-Anne Formu” ile "Çok Boyutlu Alg1lanan Sosyal Destek Ölçeği’nin Gözden Geçirilmiş Formu (ÇBASDÖ)” kullanılmıştır.

\subsubsection{Genel Bilgi Formu}

Araştırmacılar tarafindan hazırlanan Genel Bilgi Formu, araştırmaya katılan öğrencilerin cinsiyet, yaş, kardeş sayısı, anne-baba eğitim durumu, anne-baba çalışma durumu ve anne-baba tutumunu belirlemeye yönelik kapalı uçlu sorulardan oluşmuştur.

\subsubsection{Yakın İlişkilerde Yaşantılar Envanteri II (YİYE-II) - Orta Çocukluk Ölçeği-Anne Formu}

Brenning, Soenens, Braet ve Bosmans (2011) tarafindan orta çocukluk döneminde ebeveynlere bağlanma boyutlarını ölçmek amacıyla geliştirilen Yakın İlişkilerde Yaşantılar Envanteri II, Kırımer, Akça ve Sümer (2014) tarafından çocukların yalnızca annelerine olan kaygılı ve kaçınan bağlanma düzeylerini ölçmeye yönelik olarak uyarlanmıştır. Brenning, Soenens, Braet ve Bosmans (2011) orijinal çalışmalarında ölçeğin iki faktörlü yapısının, anneye bağlanma ölçeğinde toplam varyansın \% 44.36 sını açılkladığını ve ölçeğin kaygılı bağlanma boyutunun $(\alpha=.83)$ kaçınan bağlanma boyutunun $(\alpha=.85)$ yüksek iç tutarlık katsayısına sahip olduğunu göstermiştir. Kırımer, Akça ve Sümer (2014)'in çalışmasında çocukların yalnızca annelerine olan kaygılı ve kaçınan bağlanma düzeylerini ölçmeye yönelik yapılan faktör analiz sonuçları YIYYE-II - Orta Çocukluk Ölçeği Anne Formu'nun bağlanma kaygısı ve kaçınma boyutlarını temsil eden, iç tutarlı̆̆ı yüksek iki faktörlü yapıya sahip olduğunu göstermiştir. Ölçeğin bağlanma kayg1sı boyutunun $(\alpha=.78)$ kaçınan bağlanma boyutunun $(\alpha$ =.79) yüksek iç tutarlık katsayısına sahip olduğunu göstermiştir. Bağlanma kaygisı (örn., "Annemin, benim onu sevdiğim kadar beni sevmediğinden endişe duyuyorum”) ve kaçınma (örn., "Sorunlarım ve endişelerim hakkında annemle konuşurum") boyutları 18 madde ile ölçülmektedir. İki boyutta da yüksek puanlar anneye görece yüksek kaygılı ve/ya kaçınan bağlanmaya karşılık gelmektedir. Ölçeğin derecelendirmesi, orijinal çalışma temel alınarak 1 ila 7 puan aralı̆̆ında sunulmuştur ( $1=$ hiç katılmıyorum, $7=$ tamamen katıllyorum). Bağlanmanın kaygı ve kaçınma boyutlarının düşük düzeyleri güvenli bağlanmayı temsil edecektir.

\subsection{3. Çok Boyutlu Algılanan Sosyal Destek Ölçeği'nin Gözden Geçirilmiş Formu (ÇBASDÖ)}

Amerika Birleşik Devletleri'nde Zimet, Dahlem, Zimet ve Farley (1988) tarafindan geliştirilen Eker, Arkar ve Yaldız (2001) tarafından geçerlilik ve güvenirlik çalışması yapılan "Çok Boyutlu Algılanan Sosyal Destek Ölçeği’nin Gözden Geçirilmiş Formu (ÇBASDÖ)” üç farklı kaynaktan (aile, arkadaş ve özel bir insan) alınan sosyal desteğin yeterliliğini öznel olarak değerlendiren, 12 maddeden oluşan bir ölçektir. Her biri dört maddeden oluşan sosyal desteğin kaynağına ilişkin üç grubu içerir. Önerilen alt ölçek yapısı; "aile”, "arkadaş” ve “özel bir insan”dan alınan desteği içermektedir. Faktör analizi üç faktörlü yapıyı desteklemektedir. Ölçeğin ve alt ölçeklerin iç tutarllığı ve test-tekrar test korelasyonları yeterlidir. ÇBASDÖ‘nin güvenirlik katsayıSı $\alpha=.89$ olarak hesaplanmıştır. ÇBASDÖ ve alt ölçeklerinin iç tutarllıkları kabul edilebilir düzeyde bulunmuştur. Ölçekte her madde 7 aralıklı bir ölçek kullanılarak; Kesinlikle hayır=1, Kesinlikle evet=7, arasında derecelendirilmiştir. İlgili çalışmada, her alt ölçekteki dört maddenin puanlarının toplanması ile alt ölçek puanı elde edilmiş ve bütün alt ölçek puanlarının toplanması ile ölçeğin toplam puanı elde edilmiştir. Elde edilen puanın yüksek olması algılanan sosyal desteğin yüksek olduğunu ifade etmektedir. ÇBASDÖ’nin Türkçe formunun faktör yapısı, güvenirliği ve yapı geçerliği, ülkemizde kullanımı açısından, genel olarak tatmin edici bulunmuştur. Eker, Arkar ve Yaldız (2001), alt boyutlar ve ölçekten elde edilen puanın yüksek olması algılanan sosyal desteğin yüksek olduğunu ifade ettiğini belirtmişlerdir. Ölçeğin her alt boyutlarından elde edilebilecek maksimum puan 28, ölçeğin toplamından elde edilebilecek maksimum puan ise 84'dür.

\subsection{Verilerin Toplanması}

Verilerin toplanması sürecinde ölçekler uygulanmadan önce ilgili kurumlardan gerekli izinler alınmıştır. Veriler, araştırmacılar tarafindan toplanmış ve verilerin toplanmasına geçmeden önce öğrencilere çalışma ile ilgili bilgilendirme yapılmıştır. Çalışmaya katılmada gönüllülük esas alınmıştır. 


\subsection{Verilerin Analizi}

Çalışmada verilerin analizi SPSS 21.0 programı ile yapılmış ve analizlerde \%95 güven ile çalışılmıştır. Verilerin analizinde öncelikle normalliğe bakılmıştır (Green ve Salkind, 2007). Dağılımın normalliği için Shapiro-Wilk testleri yapılmıştır. Sonuçları Tablo 2'de verilmiştir.

Tablo 2.Çok boyutlu algılanan sosyal destek ve bağlanma puanlarının güvenirlik katsayısı ve normallik testi sonucu

\begin{tabular}{|c|c|c|c|c|c|c|}
\hline & & \multirow{2}{*}{$\mathbf{n}$} & \multirow{2}{*}{$\begin{array}{c}\text { Cronbach's } \\
\text { Alpha }\end{array}$} & \multicolumn{3}{|c|}{ Shapiro-Wilk } \\
\hline & & & & İstatistik & sd & $\mathrm{p}$ \\
\hline \multirow{4}{*}{$\begin{array}{c}\text { Çok Boyutlu } \\
\text { Algılanan } \\
\text { Sosyal } \\
\text { Destek }\end{array}$} & Aile boyutu & 211 & 0,741 & 924 & 211 &, 000 \\
\hline & Özel bir insan boyutu & 211 & 0,777 & ,922 & 211 & ,000 \\
\hline & Arkadaş boyutu & 211 & 0,787 & 933 & 211 & ,000 \\
\hline & Çok boyutlu algılanan sosyal destek & 211 & 0,830 & ,987 & 211 & ,049 \\
\hline \multirow{3}{*}{ Bağlanma } & Kaygı boyutu & 211 & 0,784 & ,926 & 211 & ,000 \\
\hline & Kaçınma boyutu & 211 & 0,840 & ,960 & 211 & ,000 \\
\hline & Bağlanma & 211 & 0,859 & ,966 & 211 &, 000 \\
\hline
\end{tabular}

Araştırma kapsamında ölçeklerin güvenirlik düzeylerinin belirlenmesi amacı ile Cronbach’s Alfa katsayısı hesaplanırken normal dağılıma uygunluğunun belirlenmesi amacı ile Shapiro-Wilk testi uygulanmıştır. Çok boyutlu algılanan sosyal destek ölçeği aile boyutunun Cronbach’s Alfa katsayısı 0,741, özel bir insan boyutunun 0,777 ve arkadaş boyutunun 0,787 iken çok boyutlu algılanan sosyal desteğin 0,830 olarak hesaplanmıştır.

YIYE-II - Orta Çocukluk Ölçeği Anne Formu'nun kayg1 boyutunun Cronbach’s Alfa katsayısı 0,784, kaçınma boyutunun 0,840 ve bağlanmanın (toplam) 0,859 olarak hesaplanmıştır. Cronbach's Alfa katsayısının 0-1 arasında değiştiği, değerlendirme kriterlerine göre " $0.00<0.40$ ise ölçek güvenilir değil, $0.40<0.60$ ise ölçek düşük güvenirlikte, $0.60<0.80$ ise ölçek oldukça güvenilir ve $0.80<1.00$ ise ölçek yüksek derecede güvenilir bir ölçek" olarak değerlendirildiği ifade edilmektedir (Tavşanc1l, 2005). Buna göre çok boyutlu algılanan sosyal destek ölçeği yüksek derecede, alt boyutları ise oldukça güvenilirdir. Bağlanma ölçeği ve kaçınma boyutu yüksek derecede, kaygı boyutu ise oldukça güvenilirdir.

Yapılan normallik testi sonucu ölçek puanlarının normal dağılıma uygun olmadığının belirlenmesi $(\mathrm{p}<.05)$, sebebi ile puanların değişkenlere göre farkll1ık gösterme durumunun analiz edilmesinde parametrik olmayan test tekniklerinden Mann-Whitney U ve Kruskal Wallis testleri kullanılmıştır. Mann Whitney bağımsız iki grubun nicel bir değişken açısından karşılaştırılmasında, Kruskal Wallis bağımsız k grubun $(\mathrm{k}>2)$ nicel bir değişken açısından karşılaştırılmasında kullanılan test tekniğidir.

Farklılığa yönelik yapılan analizlerde $(\mathrm{k}>2)$, anlamlı farklılık bulunan gruplardaki farklılaşmanın nereden kaynaklandığının belirlenmesinde Mann Whitney-U testi kullanılmıştır. Çalışmada öğrencilerin çok boyutlu algılanan sosyal destek ve alt boyutları ile bağlanma ve alt boyut düzeyleri arasındaki ilişkinin incelenmesi amacı ile Spearman Korelasyon testi kullanılmıştır.

\section{BULGULAR}

Araştırmaya katılan öğrencilerin görüşlerine göre anne ve babalarının sergiledikleri tutumların dağılımı Tablo 3'de yer almaktadır.

Tablo 3. Öğrencilerin görüşlerine göre anne ve babalarının sergiledikleri tutumların dağılımı (n=211)

\begin{tabular}{llrr}
\hline & & $\mathbf{n}$ & $\mathbf{0}$ \\
\hline \multirow{3}{*}{ Anne Tutumu } & Demokratik tutum & 152 & 72,0 \\
& Koruyucu tutum & 24 & 11,4 \\
& Reddedici ya da ilgisiz tutum & 12 & 5,7 \\
& Aşırı koruyucu tutum & 23 & 10,9 \\
\hline \multirow{3}{*}{ Baba Tutumu } & Demokratik tutum & 151 & 71,6 \\
& Koruyucu tutum & 24 & 11,4 \\
& Reddedici ya da ilgisiz tutum & 18 & 8,5 \\
& Aşırı koruyucu tutum & 18 & 8,5 \\
\hline
\end{tabular}

Katılımcılardan annesinin kendisine karşı tutumu demokratik olanların oranı \%72,0, koruyucu olanların $\% 11,4$, aşırı koruyucu olanların \%10,9, reddedici ya da ilgisiz olanların oranı ise \%5,7'dir. Babasının kendisine karşı tutumu demokratik olanların oranı \%71,6, koruyucu olanların \%11,4, reddedici ya da ilgisiz olanların $\% 8,5$, aşırı koruyucu olanların oranı ise \% $\%$, 'tir (Tablo 3). 
Çok boyutlu algılanan sosyal destek ve bağlanma puanlarının betimsel istatistikleri Tablo 4'de yer almaktadır.

Tablo 4. Çok boyutlu algılanan sosyal destek ve bağlanma puanlarının betimsel istatistikleri

\begin{tabular}{|c|c|c|c|c|}
\hline & & $\mathbf{n}$ & $\overline{\mathbf{X}}$ & ss \\
\hline \multirow{4}{*}{$\begin{array}{c}\text { Çok Boyutlu } \\
\text { Algılanan } \\
\text { Sosyal Destek }\end{array}$} & Aile boyutu & 211 & 20,00 & 6,51 \\
\hline & Özel bir insan boyutu & 211 & 12,35 & 6,99 \\
\hline & Arkadaş boyutu & 211 & 19,45 & 6,75 \\
\hline & Çok boyutlu algılanan sosyal destek & 211 & 51,80 & 15,54 \\
\hline \multirow{3}{*}{ Bağlanma } & Kayg1 boyutu & 211 & 44,89 & 16,01 \\
\hline & Kaçınma boyutu & 211 & 48,92 & 19,79 \\
\hline & Bağlanma & 211 & 93,81 & 29,87 \\
\hline
\end{tabular}

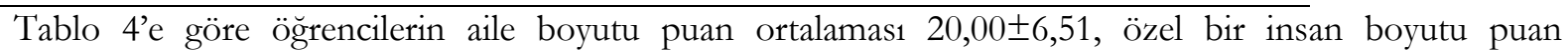
ortalaması 12,35 $\pm 6,99$; arkadaş boyutu puan ortalaması $19,45 \pm 6,75$ ve çok boyutlu algılanan sosyal destek

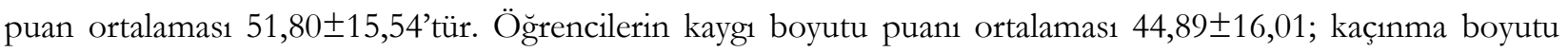
puanı ortalaması 48,92 $\pm 19,79$ ve bağlanma puanı ortalaması $93,81 \pm 29,87$ 'dir.

Çok boyutlu algılanan sosyal destek ve bağlanma alt boyutlarının ilişki analizi (kolerasyon) sonucu Tablo 5 'de yer almaktadir.

Tablo 5. Çok boyutlu algılanan sosyal destek ve bağlanma alt boyutlarının ilişki analizi (kolerasyon) sonucu

\begin{tabular}{|c|c|c|c|c|c|}
\hline & & & \multicolumn{3}{|c|}{ Bağlanma } \\
\hline & & & Kayg1 Boyutu & Kaçınma Boyutu & Bağlanma \\
\hline \multirow{8}{*}{$\begin{array}{c}\text { Çok } \\
\text { Boyutlu } \\
\text { Algilanan } \\
\text { Sosyal } \\
\text { Destek }\end{array}$} & \multirow{2}{*}{ Aile boyutu } & $R$ &,- 227 &,- 478 &,- 438 \\
\hline & & $p$ & $0,001 *$ & $0,000^{*}$ & $0,000^{*}$ \\
\hline & \multirow{2}{*}{ Özel bir insan boyutu } & $R$ & 0,012 & $-0,104$ & $-0,062$ \\
\hline & & $p$ & 0,860 & 0,134 & 0,370 \\
\hline & \multirow{2}{*}{ Arkadaş boyutu } & $R$ &,- 199 &,- 417 &,- 383 \\
\hline & & $p$ & $0,004^{*}$ & $0,000^{*}$ & $0,000^{*}$ \\
\hline & \multirow{2}{*}{$\begin{array}{l}\text { Çok boyutlu algılanan sosyal } \\
\text { destek }\end{array}$} & $R$ &,$- 176^{*}$ &,- 428 &,- 378 \\
\hline & & $p$ & $0,010^{*}$ & $0,000^{*}$ & $0,000^{*}$ \\
\hline
\end{tabular}

${ }^{*} \mathrm{p}<0,05$

Tablo 5'e göre çok boyutlu algılanan sosyal desteğin aile boyutu ile bağlanmanın kaygı boyutu arasında negatif yönlü zayıf bir ilişki bulunurken kaçınma boyutu ve bağlanma arasında negatif yönlü orta kuvvetli bir ilişki bulunmaktadır. Sosyal desteğin arkadaş boyutu ile bağlanmanın kaygı boyutu arasında negatif yönlü zayıf bir ilişki bulunurken kaçınma boyutu ve bağlanma arasında negatif yönlü orta kuvvetli bir ilişki bulunmaktadır. Çok boyutlu algılanan sosyal destek ile bağlanmanın kaygı boyutu arasında negatif yönlü zayıf bir ilişki bulunurken kaçınma boyutu ve bağlanma arasında negatif yönlü orta kuvvetli bir ilişki bulunmaktadır $(\mathrm{p}<0,05)$.

Çok boyutlu algılanan sosyal desteğin özel bir insan boyutu ile kaygılı ve kaçınan bağlanma boyutları ve bağlanma arasında bir ilişki bulunmamaktadır ( $\mathrm{p}>0,05)$.

Çok boyutlu algılanan sosyal destek ve bağlanma puanlarının sınıf değişkenine göre anlamlı düzeyde farklılaşıp farklılaşmama durumu analiz sonuçları Tablo 6'da yer almaktadır. 
Tablo 6. Çok boyutlu algılanan sosyal destek ve bağlanma puanlarının sınıf değişkenine göre farklılaşıp farklılaşmama durumunun analiz (Kruskal-Wallis) sonuçları

\begin{tabular}{|c|c|c|c|c|c|c|c|}
\hline & Sinif & & $\mathbf{n}$ & $\begin{array}{c}\text { Sira } \\
\text { Ortalamas1 } \\
\end{array}$ & $\mathbf{X}^{2}$ & $\mathbf{P}$ & $\begin{array}{l}\text { Anlamlı } \\
\text { Farklilik }\end{array}$ \\
\hline \multirow{16}{*}{$\begin{array}{l}\text { Çok boyutlu algılanan } \\
\text { sosyal destek }\end{array}$} & \multirow{4}{*}{ Aile boyutu } & 5.Sinif & 41 & 98,50 & \multirow{4}{*}{9,303} & \multirow{4}{*}{, $026^{*}$} & \multirow{4}{*}{$3-2,4$} \\
\hline & & 6.Sinif & 60 & 116,44 & & & \\
\hline & & 7.Sinif & 49 & 86,39 & & & \\
\hline & & 8.Sinif & 61 & 116,52 & & & \\
\hline & \multirow{4}{*}{ Özel bir insan boyutu } & 5.Sinif & 41 & 100,30 & \multirow{4}{*}{8,817} & \multirow{4}{*}{, $032 *$} & \multirow{4}{*}{$2-1,3$} \\
\hline & & 6.Sinif & 60 & 123,38 & & & \\
\hline & & 7.Sinif & 49 & 89,68 & & & \\
\hline & & 8.Sinif & 61 & 105,84 & & & \\
\hline & \multirow{4}{*}{ Arkadaş boyutu } & 5.Sinif & 41 & 100,88 & \multirow{4}{*}{7,884} & \multirow{4}{*}{, $048 *$} & \multirow{4}{*}{$3-2,4$} \\
\hline & & 6.Sinif & 60 & 115,73 & & & \\
\hline & & 7.Sinif & 49 & 87,13 & & & \\
\hline & & 8.Sinif & 61 & 115,02 & & & \\
\hline & \multirow{4}{*}{$\begin{array}{l}\text { Çok boyutlu algılanan } \\
\text { sosyal destek }\end{array}$} & 5.Sinif & 41 & 97,04 & \multirow{4}{*}{16,113} & \multirow{4}{*}{, $001 *$} & \multirow{4}{*}{$\begin{array}{c}1-2 \\
3-2,4\end{array}$} \\
\hline & & 6.Sinif & 60 & 124,73 & & & \\
\hline & & 7.Sinif & 49 & 80,55 & & & \\
\hline & & 8.Sinif & 61 & 114,05 & & & \\
\hline \multirow{12}{*}{ Bağlanma } & \multirow{4}{*}{ Kayg1 boyutu } & 5.Sinif & 41 & 109,98 & \multirow{4}{*}{0,604} & \multirow{4}{*}{, 896} & \multirow{4}{*}{-} \\
\hline & & 6.Sinif & 60 & 103,18 & & & \\
\hline & & 7.Sinif & 49 & 109,62 & & & \\
\hline & & 8.Sinif & 61 & 103,20 & & & \\
\hline & \multirow{4}{*}{ Kaçınma boyutu } & 5.Sinif & 41 & 102,20 & \multirow{4}{*}{1,970} & \multirow{4}{*}{, 579} & \multirow{4}{*}{-} \\
\hline & & 6.Sinif & 60 & 102,23 & & & \\
\hline & & 7.Sinif & 49 & 116,66 & & & \\
\hline & & 8.Sinif & 61 & 103,70 & & & \\
\hline & \multirow{4}{*}{ Bağlanma } & 5.Sinif & 41 & 105,99 & \multirow{4}{*}{1,580} & \multirow{4}{*}{,664 } & \multirow{4}{*}{-} \\
\hline & & 6.Sinif & 60 & 101,73 & & & \\
\hline & & 7.Sinif & 49 & 115,22 & & & \\
\hline & & 8.Sinif & 61 & 102,80 & & & \\
\hline
\end{tabular}

$*(\mathrm{p}<0,05)$

Tablo 6 incelendiğinde öğrencilerin algıladıkları sosyal destek düzeylerinin, sınıf değişkenine göre anlamlı bir farklılık gösterip göstermediğini belirlemek amacıyla yapılan "Kruskal Wallis-H” testi sonucunda çok boyutlu alg1lanan sosyal destek ve alt boyutları sıra ortalamaları arasındaki fark (aile $\mathrm{X}^{2}=9,303$; özel bir insan $\mathrm{X}^{2}=8,817$; arkadaş $\mathrm{X}^{2}=7,884$; çok boyutlu alg1lanan sosyal destek $\mathrm{X}^{2}=16,113$; $\left.\mathrm{p}<0,05\right)$ istatistiksel olarak anlamlı bulunmuştur. Bu farklılığın hangi gruplardan kaynaklandığını belirlemek üzere yapılan "Mann Whitney-U” testi sonucunda altınc1 (aile 116,44; arkadaş 115,73) ve yedinci sinıfa (aile 86,39; arkadaş 87,13) devam eden öğrenciler arasında altıncı sınıf lehine, yedinci (aile 86,39; arkadaş 87,13) ve sekizinci sınıfa(aile 116,52; arkadaş 115,02) devam eden öğrenciler arasında ise sekizinci sınıf lehine aile ve arkadaş desteği alt boyut puanlarında istatistiksel olarak anlamlı farklılık bulunmuştur $(\mathrm{p}<0,05)$.

Altınc1 $(123,38)$ ve beşinci sınıf $(100,30)$ ile altınc1 $(123,38)$ ve yedinci sınıfa $(89,68)$ devam eden ögrrenciler arasında altıncı sınıf lehine özel bir insan desteği alt boyut puanlarında istatistiksel olarak anlamlı farklılık bulunmaktadir $(\mathrm{p}<0,05)$.

Çok boyutlu algılanan sosyal destek toplam puanında beşinci $(97,04)$ ve altıncı sınıf $(124,73)$ ile yedinci $(80,55)$ ve altıncı sınıfa $(124,73)$ devam eden öğrenciler arasında altıncı sınıf lehine, yedinci sinıf (80,55) ile sekizinci sınıfa $(114,05)$ devam eden öğrenciler arasında ise sekizinci sınıf lehine istatistiksel olarak anlamlı farklılık bulunmuştur $(\mathrm{p}<0,05)$. 
Sınıfları farklı olan gruplar arasında kaygı, kaçınma ve bağlanma açısından istatistiksel olarak anlamlı farklılık bulunmamaktadır $(\mathrm{p}>0,05)$. Çok boyutlu algılanan sosyal destek ve bağlanma puanlarının annenin çocuğa karşı tutumuna göre farklılaşıp farklılaşmama analiz sonuçları Tablo 7'de yer almaktadır.

Tablo 7.Çok boyutlu algılanan sosyal destek ve bağlanma puanlarının annenin çocuğa karşı tutumuna göre farklılaşıp farklılaşmama analiz (Kruskal-Wallis) sonuçları

\begin{tabular}{|c|c|c|c|c|c|c|c|}
\hline & Annenin Tutumu & & $\mathbf{n}$ & Sira Ortalaması & $\mathbf{X}^{2}$ & $\mathbf{P}$ & $\begin{array}{l}\text { Anlamli } \\
\text { Farklılık } \\
\end{array}$ \\
\hline \multirow{16}{*}{$\begin{array}{c}\text { Çok } \\
\text { boyutlu } \\
\text { algılanan } \\
\text { sosyal } \\
\text { destek }\end{array}$} & \multirow{4}{*}{ Aile boyutu } & Demokratik tutum & 152 & 110,13 & \multirow{4}{*}{10,816} & \multirow{4}{*}{, $013 *$} & \multirow{4}{*}{$3-1,2$} \\
\hline & & Koruyucu tutum & 24 & 117,15 & & & \\
\hline & & $\begin{array}{l}\text { Reddedici ya da ilgisiz } \\
\text { tutum }\end{array}$ & 12 & 55,25 & & & \\
\hline & & Aşırı koruyucu tutum & 23 & 91,54 & & & \\
\hline & \multirow{4}{*}{ Özel bir insan boyutu } & Demokratik tutum & 152 & 110,23 & \multirow{4}{*}{3,103} & \multirow{4}{*}{,376 } & \multirow{4}{*}{-} \\
\hline & & Koruyucu tutum & 24 & 89,46 & & & \\
\hline & & $\begin{array}{l}\text { Reddedici ya da ilgisiz } \\
\text { tutum }\end{array}$ & 12 & 94,25 & & & \\
\hline & & Aşırı koruyucu tutum & 23 & 101,41 & & & \\
\hline & \multirow{4}{*}{ Arkadaş boyutu } & Demokratik tutum & 152 & 113,37 & \multirow{4}{*}{9,630} & \multirow{4}{*}{, $022 *$} & \multirow{4}{*}{$3-1,2$} \\
\hline & & Koruyucu tutum & 24 & 95,40 & & & \\
\hline & & $\begin{array}{l}\text { Reddedici ya da ilgisiz } \\
\text { tutum }\end{array}$ & 12 & 67,88 & & & \\
\hline & & Aşırı koruyucu tutum & 23 & 88,26 & & & \\
\hline & \multirow{4}{*}{$\begin{array}{l}\text { Çok boyutlu algılanan } \\
\text { sosyal destek }\end{array}$} & Demokratik tutum & 152 & 113,49 & \multirow{4}{*}{12,098} & \multirow{4}{*}{, $007 *$} & \multirow{4}{*}{$3-1$} \\
\hline & & Koruyucu tutum & 24 & 99,00 & & & \\
\hline & & $\begin{array}{l}\text { Reddedici ya da ilgisiz } \\
\text { tutum }\end{array}$ & 12 & 56,79 & & & \\
\hline & & Aşırı koruyucu tutum & 23 & 89,46 & & & \\
\hline \multirow{12}{*}{ Bağlanma } & \multirow{4}{*}{ Kayg1 boyutu } & Demokratik tutum & 152 & 103,14 & \multirow{4}{*}{2,144} & \multirow{4}{*}{, 543} & \\
\hline & & Koruyucu tutum & 24 & 104,42 & & & \\
\hline & & $\begin{array}{l}\text { Reddedici ya da ilgisiz } \\
\text { tutum }\end{array}$ & 12 & 123,58 & & & \\
\hline & & Aşırı koruyucu tutum & 23 & 117,37 & & & \\
\hline & \multirow{4}{*}{ Kaçınma boyutu } & Demokratik tutum & 152 & 101,21 & \multirow{4}{*}{8,208} & \multirow{4}{*}{,042* } & \multirow{4}{*}{$3-1,2$} \\
\hline & & Koruyucu tutum & 24 & 99,23 & & & \\
\hline & & $\begin{array}{l}\text { Reddedici ya da ilgisiz } \\
\text { tutum }\end{array}$ & 12 & 144,92 & & & \\
\hline & & Aşırı koruyucu tutum & 23 & 124,43 & & & \\
\hline & \multirow{4}{*}{ Bağlanma } & Demokratik tutum & 152 & 101,10 & \multirow{4}{*}{8,869} & \multirow{4}{*}{, $031 *$} & \multirow{4}{*}{$3-1,2$} \\
\hline & & Koruyucu tutum & 24 & 97,75 & & & \\
\hline & & $\begin{array}{l}\text { Reddedici ve ya ilgisiz } \\
\text { tutum }\end{array}$ & 12 & 144,38 & & & \\
\hline & & Aşırı koruyucu tutum & 23 & 126,96 & & & \\
\hline
\end{tabular}

$(\mathrm{p}<0,05)$

Tablo 7 incelendiğinde öğrencilerin çok boyutlu alg1ladıkları sosyal destek düzeylerinin, annenin tutumu değişkenine göre anlamlı bir farklılık gösterip göstermediğini belirlemek amacıyla yapılan analiz sonucunda çok boyutlu algılanan sosyal destek, aile ve arkadaş alt boyutları sıra ortalamaları arasındaki fark (aile $\mathrm{X}^{2}=10,816$; arkadaş $\mathrm{X}^{2}=9,630$; çok boyutlu alg1lanan sosyal destek $\left.\mathrm{X}^{2}=12,098 ; \mathrm{p}<0,05\right)$ istatistiksel olarak anlaml bulunmuştur. $\mathrm{Bu}$ farklılığın hangi gruplardan kaynaklandığını belirlemek üzere yapılan analiz sonucunda annesinin kendisine karşı tutumu reddedici ve ya ilgisiz tutum olanlar (aile 55,25; arkadaş 67,88) ile koruyucu tutum (aile 117,15; arkadaş 95,40) olanlar arasında annesi koruyucu tutuma sahip öğrenciler lehine; annesinin kendisine karşı tutumu reddedici ve ya ilgisiz tutum olanlar (aile 55,25; arkadaş 67,88) ile demokrarik tutum (aile 110,13; arkadaş 113,37) olanlar arasında ise annesi demokratik tutuma sahip ögrenciler lehine aile ve arkadaş desteği alt boyut puanlarında istatistiksel olarak anlamlı farklılık bulunmaktadır $(\mathrm{p}<0,05)$.

Çok boyutlu algilanan sosyal destek toplam puanlarında annesinin kendisine karşı tutumu reddedici ve ya ilgisiz olanlar $(56,79)$ ile demokratik tutum $(113,49)$ olanlar arasında annesi demokrarik tutuma sahip öğrenciler 
lehine istatistiksel olarak anlamlı farklılık bulunmaktadır $(p<0,05)$. Özel bir insan alt boyutunda anne tutumu değişkeni istatistiksel olarak anlamlı farklılık yaratmamaktadır $(\mathrm{p}>0,05)$.

Öğrencilerin bağlanma düzeylerinin, annenin tutumu değişkenine göre anlamlı bir farklılık gösterip göstermediğini belirlemek amacıyla yapılan analiz sonucunda bağlanma ölçeği, kaçınma alt boyut sıra ortalamaları arasındaki fark (bağlanma $\mathrm{X}^{2}=8,869$; kaçınma $\mathrm{X}^{2}=8,208 ; \mathrm{p}<.05$ ) istatistiksel olarak anlamlı bulunmuştur. $\mathrm{Bu}$ farklılığın hangi gruplardan kaynaklandığını belirlemek üzere yapılan analiz sonucunda annesinin kendisine karşı tutumu reddedici ya da ilgisiz tutum (kaçınma 144,92; bağlanma 144,38) ile demokrarik tutum (kaçınma 101,21; bağlanma 101,10)) olanlar arasında ve annesinin kendisine karşı tutumu reddedici ya da ilgisiz tutum (kaçınma 144,92; bağlanma 144,38) ile koruyucu tutum (kaçınma 99,23; bağlanma 97,75) olanlar arasında reddedici ya da ilgisiz tutum lehine kaçınma alt boyutu ve güvensiz bağlanma toplam puanında istatistiksel olarak anlamlı farkl11ı bulunmaktadır $(\mathrm{p}<0,05)$. Kayg1 alt boyutunda anne tutumu değişkeni istatistiksel olarak anlamlı farklılık yaratmamaktadır $(\mathrm{p}>0,05)$.

Yaş, cinsiyet, kardeş sayısı, anne-baba eğitim durumu, anne-baba çalısma durumu ve baba tutumu farklı olan gruplar arasında hem çok boyutlu algilanan sosyal destek ölçeği ve alt boyutlanı hem de bağlanma ölçeği ve alt boyutlarında istatistiksel olarak anlamlı farklılık bulunmamıştır ( $\mathrm{p}>0,05)$.

\section{TARTIŞMA ve SONUÇ}

Çok boyutlu algılanan sosyal destek ve bağlanma puanlarının betimsel istatistikleri incelendiğinde öğrencilerin en fazla sosyal desteği sırası ile aileden, arkadaştan ve özel bir insandan aldıkları görülmüştür. Bu durum öğrencilerin geleneksel aile yapısında yetiştikleri düşünüldüğünde en fazla aile ve arkadaşları ile iletişim içerisinde bulunmalarından kaynaklanabilir. Anneye bağlanmada kaçınma alt boyutunun kaygı alt boyutundan daha yüksek ortalama düzeyine sahip olması, çocukların özel bir insana bağlanmaktan kaçınmalarını da akla getirmektedir. Bu bulgu Brenning, Soenens, Braet ve Bosmans (2011) ve Kırımer, Akça ve Sümer (2014)'in çalışmasıyla benzerlik göstermektedir.

Çok boyutlu algılanan sosyal destek ve bağlanma alt boyutlarının ilişki analizine bakıldığında çok boyutlu algılanan sosyal desteğin aile boyutu ile bağlanmanın kaygı boyutu arasında negatif yönlü zayıf bir ilişki, kaçınma boyutu ve bağlanma arasında ise negatif yönlü orta kuvvetli bir ilişki olduğu görülmüştür. Sosyal desteğin arkadaş boyutu ile bağlanmanın kaygı boyutu arasında negatif yönlü zayıf bir ilişki bulunurken kaçınma boyutu ve bağlanma arasında negatif yönlü orta kuvvetli bir ilişki bulunmaktadır. Çok boyutlu algılanan sosyal destek ile bağlanmanın kaygı boyutu arasında negatif yönlü zayıf bir ilişki bulunurken kaçınma boyutu ve bağlanma arasında negatif yönlü orta kuvvetli bir ilişki bulunmaktadır. Çok boyutlu algılanan sosyal desteğin özel bir insan boyutu ile kaygilı ve kaçınan bağlanma boyutları ve bağlanma arasında bir ilişki bulunmazken, aile ve arkadaş alt boyutlarında, çok boyutlu algılanan sosyal destek arttıkça kaygı, kaçınma ve bağlanma azalmaktadır. Kırımer, Akça ve Sümer (2014), bağlanmanın kaygı ve kaçınma boyutlarının düşük düzeyinin güvenli bağlanmayı işaret ettiğini ifade etmişlerdir. Bu durum öğrencilerin sosyal destek aldıkça annelerine bağlanmalarında kaygı ya da kaçınma yaşamadıklarını göstermektedir. Diğer bir deyişle kaygılı ya da kaçınan bağlanma yaşayan öğrenciler sosyal destek aldıkça anneye güvenli bağlanma düzeyleri artmaktadır.

Çok boyutlu algilanan sosyal destek ve bağlanma puanlarının sınıf değişkenine göre farklılaşıp farklılaşmama durumu incelendiğinde aile ve arkadaş desteği açısından alıncı ve yedinci sınıfa devam eden öğrenciler arasında altıncı sınıf lehine istatistiksel olarak anlamlı farklılık bulunmaktadır. Altıncı sınıfa devam eden öğrencilerin yedinci sınıfa devam eden öğrencilere göre daha fazla aile ve arkadaş desteği almaları, ergenlik öncesi döneme özgü bazı "kırılganlıkların” yaşandığı geç çocukluk döneminde bu zorluklarla baş etmede aile desteğinin yanında arkadaş desteğine de başvurduklarını akla getirmektedir. Literatürde de, 12 yaşa denk gelen altıncı sınıf lehine anlamlı farklılık olduğunu belirten çalısmalara rastlanmaktadır (Lieberman, Doyle ve Markiewicz 1999; Verschueren ve Marcoen, 2005; Sümer ve Anafarta-Şendağ 2009).

Aile ve arkadaş desteği açısından yedinci ve sekizinci sınıfa devam eden öğrenciler arasında ise sekizinci sınıfa devam eden öğrenciler lehine istatistiksel olarak anlamlı farklılık bulunmaktadır. Sekizinci sınıfa devam eden öğrencilerin yedinci sınıfa devam eden öğrencilere göre daha fazla aile ve arkadaş desteği almaları ortaokul son sınıfta olmaları nedeni ile arkadaşlarından ayrılma, sosyal ve ekonomik nedenlerden dolayı lise 
eğitimine devam edememe gibi korkularından dolayı daha fazla aile ve arkadaş desteğine başvurmalarından kaynaklanmış olabilir.

Çok boyutlu algılanan sosyal destek puanlarında beşinci sınıf ile altıncı sınıfa devam eden öğrenciler arasında ve altıncı sınıf ile yedinci sınıfa devam eden öğrenciler arasında altıncı sınıfa devam eden ögrenciler lehine istatistiksel olarak anlamlı farklılık bulunmaktadır. Yedinci sınıf ve sekizinci sınıfa devam eden öğrenciler arasında ise sekizinci sınıf lehine istatistiksel olarak anlamlı farklılık bulunmaktadır. Sekizinci sınıfa devam eden öğrencilerin yedinci sınıfa devam eden öğrencilere göre çok boyutlu algılanan sosyal destek puanlarının yüksek olması sekizinci sınıfların geçiş dönemi olmasından kaynaklanabilir. Anneye bağlanma, kaçınma ve kayg1 boyutlarında sınıf değişkenine göre istatistiksel olarak anlamlı farklılık bulunmamıştır. Bu durum bağlanma şeklinin 4 yll gibi bir sürede değişemeyeceğini orta çocukluk dönemine gelene kadar bir çok kritik dönemin geride kaldığını akla getirmektedir. Kırımer, Akça ve Sümer (2014) çalışmalarında bu bulguya benzer olarak bağlanmanın kaygı boyutunun yaşa göre değişmediğini, ancak yaş arttıkça kaçınan bağlanma düzeylerinin azaldığını belirtmişlerdir.

Çok boyutlu algılanan sosyal destek ve bağlanma puanlarının annenin çocuğa karşı tutumuna göre farklılaşıp farklılaşmama durumuna bakıldığında annesi reddedici ya da ilgisiz tutum sergileyen öğrencilerin annesi demokrarik tutum sergileyen öğrencilere göre aile, arkadaş ve sosyal desteğe daha az başvurdukları görülmüştür. Reddedici ya da ilgisiz tutuma maruz kalan öğrencilerin reddedilme kaygısı ile aile, arkadaş ve sosyal desteğe daha az başvurdukları, demokratik anneye sahip öğrencilerin ise sosyal ilişkilerinde daha bağımsız hareket ettikleri söylenebilir. Nitekim, Baldwin ve Watson, hoşgörülü ve demokratik evlerde büyüyen çocukların arkadaşları ile ilişkilerinde daha etkin, daha girişken, yaratıcı fikirler ileri sürebilen, fikirlerini serbestçe söyleme eğilimi gösteren çocuklar olduklarını belirtmişlerdir (Baldwin ve Watson'dan aktaran Yavuzer, 1993). Literatürde bu bulguyu destekler nitelikte çalışma bulunmaktadır (Sağlam, 2007).

Annesinin kendisine karşı tutumu koruyucu tutum olanların aile ve arkadaş desteğine başvurmaları annesinin tutumu reddedici ya da ilgisiz tutum olan öğrencilere göre daha fazladır. Bu durum annelerin koruyucu tutum sergilemelerinden dolayı çocukların bağımsız hareket etmekte zorlandıklarını ve daha sık aile ve arkadaş desteğine başvurduklarını akla getirmektedir. Nitekim, Bronfenbrenner araştırmasında annenin koruyucu tutumunun çocuklarda bağımsızlık, girişim ve kendine yeterlilik gibi kişilik özelliklerini olumsuz etkilediğini ifade etmiştir (Bronfenbrenner'den aktaran Sağlam, 2007).

Bağlanma puanlarının annenin çocuğa karşı tutumuna göre farklılaşıp farklılaşmama durumuna bakıldığında annesi reddedici veya ilgisiz tutuma sahip öğrencilerin demokratik ve koruyucu tutuma sahip öğrencilere göre kaçınma ve güvensiz bağlanma düzeyleri daha yüksektir.

Yaş, cinsiyet, kardeş sayısı, anne-baba eğitim durumu, anne-baba çalısma durumu ve baba tutumu farklı olan gruplar arasında hem çok boyutlu alg1lanan sosyal destek ölçeği ve alt boyutlanı hem de bağlanma ölçeği ve alt boyutlarında istatistiksel olarak anlamlı farklılık bulunmamaktadır.

Araştırma sonuçlarına yönelik olarak; sosyal dezavantajlı bölgelerde aile eğitim programlarının yaygınlaştırılması ve özellikle baba katılımını arttırmaya yönelik teşviklerin yapılması, sosyal dezavantajlı okullarda, çocuk gelişimi ve sosyal hizmet uzman kadrolarına yer verilmesi ve bu kadroların rehberlik ve psikolojik danışman öğretmenler ve okul yönetimi ile koordineli çalısması, rehberlik ve psikolojik danışman öğretmenlerin sosyal ilişkilerinde güvensizlik yaşayan çocukları tespit etmeye özen göstermesi çocuğa ve aileye gerekli yönlendirmeleri yapması, araştırmanın daha büyük örneklemler ile boylamsal ve karma yöntemde tekrarlanması, sosyal dezavantajı bölgelere yönelik veri toplama araçlarının geliştirilmesi önerilebilir.

\section{KAYNAKÇA}

Ainsworth, M. D., Blehar, M. C., Waters, E. ve Wall, S. (1978). Patterns of attachment: A psychological study of the strange situation. Hillsdale, NJ: Erlbaum.

Baltacı, H. Ş. ve Karataş, Z. (2015). Ortaokul öğrencilerinin y1lmazlık düzeylerinin yordayıcısı olarak algılanan sosyal destek, depresyon ve yaşam doyumu: Burdur Örneği. Eurasian Journal of Educational Research, 15(60), 111-130. 
Bowlby, J. (1973). Attachment and loss Vol II: Seperation. New York: Basic Books.

Bowlby, J. (1982). Attachment and loss: Vol I. Attachment (2. bask1). New York: Basic Books.

Brenning, K., Soenens, B., Braet, C. ve Bosmans, G. (2011). An adaptation of the experiences in close relationships scalerevised for use with children and adolescent. Journal of Social and Personal Relationships, 28, 1048-1072.

Büyüköztürk, Ş., K1liç-Çakmak, E., Akgün, Ö.E., Karadeniz, Ş. ve Demirel, F. (2017). Bilimsel araştırma yöntemleri (19. Baskı). Ankara: Pegem Akademi.

Cassidy, J. (1999) The nature of the child's ties. J. Cassidy ve P. Shaver, (Ed.), Handbook of attachment: Theory, research and clinical applications. New York: Guilford.

Cobb, S.(1976). Social support as a Mediator of Life Stres. Psychosomatic Medicine, 38, 300-314.

Çakmak, A. ve Şahin, H. (2017).Ortaokula devam eden öğrencilerin algıladıkları sosyal desteğin okul tükenmişliğine etkisinin incelenmesi. Elektronik Sosyal Bilimler Dergisi, 16(61), 569-582.

Eker, D., Arkar, H. ve Yaldız, H. (2001). Çok Boyutlu Algılanan Sosyal Destek Ölçeği’nin Gözden Geçirilmiş Formunun faktör yapıs1, geçerlik ve güvenirliği. Türk Psikiyatri Dergisi, 12 (1), 17-25.

Green, S.B. ve Salkind, N.J. (2007). Using SPSS for windows and macintosh: analyzing and understanding data. Upper Saddle River, NJ: Pearson Education Inc.

Karadağ, İ.(2007).̇llkëğretim beşinci sinnf ögrrencilerinin akademik başarlarmm sosyal destek kaynaklar açısmdan incelenmesi, Yüksek Lisans Tezi, Çukurova Üniversitesi Sosyal Bilimler Enstitüsü, Adana.

Kırımer, F., Akça, E. ve Sümer, N. (2014). Orta çocuklukta anneye kaygılı ve kaçınan bağlanma: Yakın İlişkilerde Yaşantılar Envanteri-II orta çocukluk dönemi ölçeğinin Türkçe’ye uyarlanması. Türk Psikoloji Yazılar 17(33), 45-57.

Levitt, M. J., Guacci-Franco, N., \& Levitt, J. L. (1994). Social support and achievement in childhood and early adolescence: A multicultural study. Journal of Applied Developmental Psychology, 15, 207-222.

Lieberman, M., Doyle, A. B. ve Markiewicz, D. (1999). Developmental patterns in security of attachment to mother and father in late childhood and early adolescence: Associations with peer relations. Child Development 70 (1), 202-213.

Main, M., Kaplan, N. ve Cassidy, J. (1985). Security in infancy, childhood, and adulthood: A move to the level of representation. Monographs of The Society for Research in Child Development, 50(1-2), 66104.

Nowakowska, S. S. (2014). Measuring adolescents' perceptions of academic social support: the relationship between academic social support, global social support, and level of functioning. Master's thesis, Northern Illinois University, DeKalb, IL.

Öztürk H. ve Şirin A. (2000).Doğum yapan annelerde alg1lanan sosyal destek faktörlerinin ve bunlara etki eden faktörlerin incelenmesi. Ege Üniversitesi Hemşirelik Yüksek Okulu Dergisi, 16, 31-40.

Sağlam, S.(2007).Lise ögrencilerinin ana-baba iletişimi sosyal destek ve ana-baba tutumu arasindaki iliş̧kilerin incelenmesi. Yüksek Lisans Tezi.Atatürk Üniversitesi Sosyal Bilimler Enstitüsü, Erzurum.

Şahan, B. ve Duy, B. (2017). Okul tükenmişliği: okula bağlanma, sosyal destek ve öz yeterliliğin yordayıc1 rolü. Mersin Üniversitesi Eğitim Fakültesi Dergisi, 13(3), 1249-1270.

Sumbaş, E. ve Sezer, Ö.(2017).Ortaokul öğrencilerinin anne babaya bağll1kllarının incelenmesi. Ege Eğitim Dergisi, 1(18), 288-310.

Sümer, N. ve Anafarta-Şendağ, A.(2009). Orta çocukluk döneminde ebeveynlere bağlanma, benlik algisı ve kayg1. Türk Psikoloji Yazlar 24(63), 86-101.

Tavşanc1l, E.(2005).Tutumlarn ölçülmesi ve SPSS ile veri analiz̨. Ankara: Nobel.

Temel, Z. F. ve Aksoy, A.(2016).Ergen ve gelişimi (4.Basim).Ankara:Nobel.

Ünal, A.Ö.(2011).Lise ögrencilerinin yaşam doyumlarmm baz̨ değişkenlere göre yordanması.Yüksek Lisans Tezi, Karadeniz Teknik Üniversitesi, Sosyal BilimlerEnstitüsü, Trabzon. 
Verschueren, K. ve Marcoen, A. (2005). Perceived security of attachment to mother and father: Developmental differences and relations to self-worth and peer relationships at school. K. A. Kerns ve R. A. Richardson, (Ed.), Attachment in middle childhood içinde (212-230). New York: Guilford.

Yavuzer, H.(1986).Ergenlik çağında gelişmeyi etkileyen gücler.İstanbul:Boğaziçi Üniversitesi.

Yavuzer, H.(1993).Çocuk psikolojisi.İstanbul:Remzi Kitabevi.

Yıldırım, İ. (1998).Akademik başarı düzeyleri farklı olan lise öğrencilerinin bazı değişkenlere göre sosyal destek düzeyleri.Türk Psikolojik Danıșa ve Rebberlik Dergisi 2, (10),33- 45.

Zimet, G.D., Dahlem, N.W., Zimet, S.G. ve Farley, G.K.(1988). The Multidimensional Scale of Perceived Social Support. Journal of Personality Assessment, 52, 30-41.

\section{Citation Information}

Bekir, H., Arbaş, G. \& Aydın, R. (2018). Sosyal Dezavantajlı Bölgedeki Ortaokul Öğrencilerinin Anneye Bağlanma ve Sosyal Destek Alg1s1. Dicle Üniversitesi Ziya Gökalp Ë̆itim Fakültesi Dergisi, 33, 79-90. 